\title{
Innovation and Development Strategies of Visual Communication Design Education in the Internet Era
}

\author{
Wanqiu Wang ${ }^{1}$ \\ ${ }^{1}$ City College, Wuhan University of Science and Technology, Wuhan, Hubei, China
}

Keywords: Internet era; Visual communication design Education; The development strategy

\begin{abstract}
The advent of the Internet era has brought about the transformation of design media, design methods and design forms. The education mode of visual communication design major at various colleges and universities has not been improved according to the changes of the times, which leads to the fact that the professionals who are finally trained cannot meet the needs of employers. Based on the current situation of visual communication design education in colleges and universities, the author analyzes the opportunities and challenges faced by the development of visual communication design education in the Internet era, and puts forward a series of strategies for the innovation and development of visual communication design education.

Due to the influence of late start and slow development, visual communication design education in colleges and universities still faces some outstanding difficulties and problems, which has become a major bottleneck restricting the development of design education and education in China. In the context of the Internet era, faced with the new educational development situation, we must start from the present situation of visual communication design education, carry out relevant research work actively, and re-examine the educational thinking so as to ensure the sustainable development of our design education.
\end{abstract}

\section{Current Situation of Visual Communication Design Education}

In the context of the Internet era, visual communication design has broken the traditional pattern of the layout of basic plane elements such as text and graphics in the two-dimensional space. Because changes in the media environment have changed the art design dissemination ways, a series of analog electronic media and communication technologies continue to intervene in the art design at the technical application level. In the era of Internet dominated electronic information dissemination, visual communication design has made revolutionary expansion and breakthroughs in both content and scope of dissemination. Diversification leads to the confusion period of visual communication design education, there are many paths and many problems are faced, and the ways to solve them are more than before. In this context, it is necessary to seriously consider the core content of the development of visual communication design education and the problems to be solved.

\section{The Orientation of Talent Training Goals is Backward}

From the perspective of training objectives of visual communication design major in universities, it is mainly to train professionals who can engage in advertising, corporate planning, newspaper and other units in product packaging, commercial advertising and corporate image design. However, from the analysis of graduates of visual communication design in recent years, there are few students who can meet these recruitment requirements, which is directly related to the aging of personnel training mode at schools. A considerable number of colleges and universities put the goal of training visual communication design professionals on improving students' design skills. Although students' professional ability can also be enhanced while strengthening students' design skills, they lack the cultivation of students' emotion and values and the development of innovative thinking in the Internet era, which leads to the low comprehensive quality of trained professionals.

\section{Teaching Contents and Teaching Methods are Obsolete}

Visual communication design education has its own particularity. In the compilation of curriculum contents, we should set up the characteristics and teaching practice of visual communication design education, so as to teach students in accordance with their aptitude. Teaching methods should also be adapted to local conditions and vary from person to person, 
breaking away from the confinement of traditional classroom teaching, walking into life and going to society, and integrating theory knowledge with practice. However, at present, the focus of visual communication design is still on improving students' professional theoretical knowledge with a lack of education about students' application of professional knowledge and professional skills, particularly the cultivation of students' practical abilities. Thus, the function of education cannot be fully played out, which is not conducive to the cultivation of comprehensive talents and makes it difficult to develop visual communication design education.

\section{Visual Communication Design Education in the Context of the Internet Era}

From the PC era to the age of the Internet, the digital field has expanded rapidly from the individual to the global. The Internet has brought the social cultural communication to a new era. People's daily life has already been separated from the Internet. It can be said that as the mass media in the new era, the Internet has greatly changed people's life. The internet shortens the distance between time and space. The whole world is contracted into a new dimension space. We can browse the world's customs in real time, and the information transmission is fast, wide, timely, cheap and interactive. Compared with the traditional media mode, the Internet has many distinct advantages.

In the Internet era, the amount of information data is huge, the speed of dissemination is fast, the speed of information processing and the efficiency of application will increase exponentially. These characteristics provide good conditions for information transmission of visual communication design, but will also cause fierce competition among designers. For the field of design, the designer takes the information elements of the Internet through its own aesthetic accomplishment and creative experience.

The design works integrated and processed through the software platform is more timely. The visual impact of visual communication design has gradually influenced and changed people's habits, values and aesthetics through information and digital media, and has become an important source of people's knowledge intake. The popularity of the Internet has injected fresh blood into the professional education of visual communication design, which brings opportunities and challenges. The static media era cannot meet the needs of the new century, visual design education is increasingly surpassing the previous category to the wider field.

\section{Strategies for the Innovative Development of Visual Communication Design Education in the Era of the Internet}

\section{Innovate School-Running Model}

The school should change the traditional single school-running model, and change the closed teaching for all aspects of the open school. On the one hand, colleges and universities should take cooperation as a link to strengthen cooperation between schools and well-known design companies to provide students with real learning environment and improve their professional quality and competitiveness. Only by participating in the actual position can students exercise their practical ability in practical operation, understand their own shortcomings, and point out directions for future learning. On the other hand, universities can strengthen exchanges and cooperation with the creative design company, construct the integrated talent training mode of "school -enterprise-society" and compose a project team to allow students to master various knowledge and skills needed in the project analysis, design to the final implementation, including team spirit, demand analysis and project implementation capacity, etc.

\section{Reform Talent Training Model}

At present, there are several directions to reform the major at domestic colleges and universities, and the cultivation is carried out towards a certain direction without changing the name of the major, but the actual result is that: art design majors have better software design and aesthetic accomplishment, but they are not familiar with brand creativity and marketing in the Internet age. The focus of visual communication training is clear understanding and scientific analysis of the market demand, and all the products and information in the market are integrated into Internet+. In 
this major, graphic design and creation should also be connected to the webpage and APP. Specifically, the graphic design materials are introduced into the mobile Internet to become a part of the Internet + so as to highlight the unique professional advantages and new development direction different from the extensive subject positioning of "graphic design" or "art design". Secondly, based on the college's faculty resources to connect advertising design, digital media and animation courses so that students can select all these courses for complementary advantages and cooperative development. Based on adaptability, the professional direction focuses on visual communication, advertising creativity and production based on mobile Internet communication technology. It focuses on training senior professional talents who have both creative design skills and knowledge of Internet communication.

\section{Improve Course Setting}

To improve the quality of university personnel training, we need to really concern about the personality of students, and let excellent teachers return to teaching. We need to keep pace with the times and improve curriculum settings, and we need to promote general education more objectively and rationally. The professional curriculum can be composed of "three teaching modules", namely: art design module + advertising module + practical operation module; Specific practices include: creative courses (advertising creative planning, brand marketing communication, etc.); design courses (advertising photography, UI design, FLASH, Photoshop, Corel DRAW, webpage design and production, animation design, etc.) "What's learned from books is superficial after all. It's crucial to have it personally tested somehow." Main course such as "creative graphic design", "commercial poster design" and "brand series of packaging design" should be incorporated into "advertising planning and creative design", which should be divided into "advertising planning and creation principles" and "advertising creation and design practice", etc. A wider range of pre distributed courses are integrated into big creative design courses.

\section{Optimize the Teaching Methods}

In view of professional characteristics, curriculum system and practical application needs, we should do our best to provide students with some textbooks and teaching contents that meet the needs of professional learning. We can introduce project based teaching methods and improve the proportion of practice. Colleges and universities should start from the Internet + era's requirements for the knowledge, skills and qualities of visual communication design professionals to construct a curriculum system that can help to improve visual communication design majors' practical ability so that students can improve their own visual communication design abilities through practical training. The concrete practice is as follows: establishing the training room to provide environmental support for the reform and innovation of professional teaching. The training room is equipped with a series of models and teaching aids related to visual communication design courses, as well as computers, printers, scanners, recorder, digital cameras, digital cameras and other machine equipment, to provide students with practical operation environment for hands-on mapping and design, make them feel the charm of the course directly and improve their design ability.

Meanwhile, teachers should pay attention to the curriculum teaching methods. The theoretical knowledge of any discipline tends to be boring, so teachers better combine theoretical knowledge and practice to stimulate students' interest in learn, motivate their enthusiasm in participating in the classroom activities and improve the teaching effect.

\section{Emphasize Students' Scientific Accomplishments}

We should strengthen the basic foreign language teaching and pay more attention to the cultivation of the ability of language application. Bilingual courses are set up and foreign language teaching materials are used to strengthen the students' ability to use professional foreign language, such as reading materials. We should strengthen computer practice, cultivate students' computer application ability, skillfully use computers to do graph processing, encourage students to take courses in science and technology and participate in social practice, especially focus on training students' scientific quality. 


\section{Improve the Evaluation System}

First, colleges and universities should break through the confinement of the traditional paper assessment model and adopt the multi-mode evaluation method. On the one hand, it is to strengthen the assessment of the school curriculum. In addition to assessing students' professional knowledge, we should also strengthen the new examination contents such as hands-on operation, cartography, design, creativity and manuscript. We should set up thinking questions and contact questions bank, and carry out the analysis system of course professors and examinations.

Second, strength assessment of students during internship. For the assessment of students' internship performance and ability, students' internship report and practice identification form submitted cannot be regarded as the sole assessment standards, but the school should formulate the student management regulations and practice standards together with the internship unit. At the internship stage, the supervision of the teachers in the school is carried out by the school, and the comprehensive evaluation of the students' post internship stage is issued by the enterprises. Students who do not pass the practice should extend their period of practice so that they can grow up in their work to ensure that they can learn something from the internship.

\section{Conclusion}

The Internet will play an important role for a long time for the foreseeable future. Therefore, with the expansion of the development scale of the design industry, the requirements of the society for the professionals of visual communication design will also change. More and more attention will be paid to the professional skills and comprehensive qualities of the students. In the era of the Internet, the education of visual communication design based on the Internet age must first grasp the sense of the times. In different times, we need to design education with different characteristics of the times, so as to reflect the imprint of contemporary people's ideals and times on social civilization. Colleges and universities should start from the needs of the visual communication design talents, carry out the comprehensive innovation of educational thinking, and train all-round innovative and comprehensive professionals, so as to promote the healthy and stable development of China's design industry.

\section{References:}

[1] CAO Fang, Principles of Visual Communication Design [[M]. Nanjing: Jiangsu Art Publishing House, 2012.

[2] WANG Lina. Discussion of Visual Communication Design Teaching Model in the Era of the "Internet"[J]. Sea of Art, 2017(7).

[3] ZHANG Nanna. On the Art Design Studio's Teaching Model in the Era of the "Internet" Take Visual Communication Design as an Example[J]. Art and Technology, 2016(4).

[4] LIU Yuhan. On the Methods and Performance Characteristics of Visual Communication Design in the Internet Age[J]. Art Education, 2017(10).

[5] YU Jiajia, Yi Yanbo. Visual Form in Visual Communication Design[J]. Art Education, 2010(02).

[6] LI Pingping. Research on the Training Mode of Visual Communication Design Professionals in the Context of Mobile Internet[J]. Art and Technology, 2015(6).

[7] YANG Mang. Curriculum Design and Exploration of Visual Communication Design[J]. Journal of Leshan Teachers College, 2011(8).

[8] Lu Jianzhou. A Preliminary Study on the Course Setting of the Decoration Design Major[J]. Light Industry Education in China, 2012(02).

[9] Ren Wei. Problems and Countermeasures of Visual Communication Major's Courses in the Era of the "Internet"[J]. Art and Technology, 2017(3). 
[10]ZHENG Peicheng. Reform and Exploration in Various Fields - Research on the Teaching Reform and Innovation of the Visual Communication Design Major under the Internet Thinking[J]. Popular Literature and Art, 2017(9). 